\title{
Impaired Response of Fibroblasts from Patients with Hyperapobetalipoproteinemia to Acylation-stimulating Protein
}

\author{
Katherine M. Cianflone, ${ }^{\star *}$ Magdalena H. Maslowska, ${ }^{*}$ and Allan D. Sniderman* \\ ${ }^{*} M c G i l l$ Unit for the Prevention of Cardiovascular Disease, Royal Victoria Hospital, Montreal, Quebec H3A 1A1; and \\ ${ }^{\ddagger}$ Department of Chemistry and Biochemistry, Concordia University, Montreal, Quebec H3G 1M8, Canada
}

\begin{abstract}
Acylation-stimulating protein (ASP) is a small, basic, human plasma protein that markedly stimulates triglyceride synthesis in human adipocytes and cultured human skin fibroblasts. The present studies examine the response to ASP of cultured skin fibroblasts from normal subjects patients with hyperapobetalipoproteinemia, patients with familial hypercholesterolemia, and patients with hypertriglyceridemia without hyperapobetalipoproteinemia. Triglyceride synthesis induced by ASP did not differ significantly among the normals, the patients with familial hypercholesterolemia, and the patients with hypertriglyceridemia with normal low density lipoprotein (LDL) apolipoprotein B levels; however, on average, it was markedly reduced in the patients with hyperapobetalipoproteinemia. In all groups studied, evidence of specific saturable binding of radioiodinated ASP was present. Binding, however, was significantly reduced in the groups with hyperapobetalipoproteinemia whereas the other three groups were indistinguishable. By contrast, LDL-specific binding was reduced only in the patients with familial hypercholesterolemia. There was a significant direct relation between the degree of ASP binding and the triglyceride synthesis inducible by ASP. In addition, with the exception of the patients with familial hypercholesterolemia, there was an inverse relation between both ASP-specific binding and ASP-induced triglyceride synthesis in fibroblasts to LDL levels in plasma whereas no relation was evident to plasma high density lipoprotein and very low density lipoprotein. (J. Clin. Invest. 1990. 85:722-730.) hyperapobetalipoproteinemia $\bullet$ acylation-stimulating protein - regulation of triglyceride synthesis
\end{abstract}

\section{Introduction}

Increased numbers of low-density lipoprotein (LDL) particles in plasma are a common abnormality in patients with premature coronary artery disease. Plasma LDL particle number can increase either because of impaired catabolism of LDL such as occurs, for example, in familial hypercholesterolemia (1), or because of increased production such as occurs in hyperapobetalipoproteinemia (hyperapoB) ${ }^{1}(2)$. The specific faults in

Address reprint requests to Dr. Sniderman, Cardiology Division, Royal Victoria Hospital, 687 Pine Avenue West, Montreal, Quebec H3A 1A1, Canada.

Received for publication 5 June 1989 and in revised form 29 September 1989.

1. Abbreviations used in this paper: hyperapoB, hyperapobetalipoproteinemia.

J. Clin. Invest.

(c) The American Society for Clinical Investigation, Inc.

0021-9738/90/03/0722/09 \$2.00

Volume 85, March 1990, 722-730 the LDL pathway that result in familial hypercholesterolemia have been explicated in considerable detail whereas the basis, or bases, for the increased hepatic synthesis of apolipoprotein B (apoB) 100 lipoprotein particles in hyperapoB are unknown.

In the course of studies comparing fatty acid metabolism in peripheral tissues from normal subjects and patients with hyperapoB, we serendipitously recognized the presence in human plasma of a factor which markedly stimulated triglyceride synthesis in skin fibroblasts cultured from normals (3). However, cells from patients with hyperapoB were much less responsive to this factor (4). The protein responsible for this activity has now been purified to homogeneity and named acylation-stimulating protein (ASP) (5). The purpose of the present studies is to compare the response to ASP of skin fibroblasts from normals with those from patients with hyperapoB, as well as with those from patients with familial hypercholesterolemia and hypertriglyceridemia with normal LDL apoB levels.

\section{Methods}

Lipid and apolipoprotein assays. Plasma total cholesterol and triglyceride, high density lipoprotein (HDL) cholesterol, LDL cholesterol, and plasma $L D L$ apoB were measured in fasting samples obtained from all subjects. Plasma cholesterol and triglyceride were measured by enzymatic determination (Nos. 237574 and 701.904, respectively, Boehringer-Mannheim Diagnostics, Houston, TX). HDL was measured by the heparin-manganese method (6) and LDL cholesterol was calculated according to the method of Friedewald et al. (7). Plasma LDL apoB was measured by radial immunodiffusion (8). The normal ranges for plasma and lipoprotein lipids were taken from the Lipid Research Clinics Prevalence Study (9). A value of plasma LDL apoB $>120 \mathrm{mg} / \mathrm{dl}$ was taken to be elevated (10) and the diagnosis of hyperapoB made on the basis of an elevated LDL apoB with a LDL cholesterol to apoB ratio < 1.5:1 (11). The diagnosis of familial hypercholesterolemia was made clinically (12) but also was based on the presence of an elevated LDL cholesterol with an LDL cholesterol to apoB ratio of $1.8: 1$ or greater (11).

ASP purification. ASP was purified by a modification of the original method (5). Frozen human plasma was thawed at $4^{\circ} \mathrm{C}$ overnight. The plasma was centrifuged at $2,000 \mathrm{rpm}$ for $20 \mathrm{~min}$ and the supernatant was then filtered to remove the precipitate. Plasma was applied to a Fast-Flow-S-Sepharose column (Pharmacia, Uppsala, Sweden) (14 $\mathrm{ml} / \mathrm{ml}$ gel) and washed with seven column volumes of buffer $\mathrm{A}(0.02 \mathrm{M}$ phosphate, $\mathrm{pH} 7.1$, with $0.02 \%$ sodium azide). The bound protein fraction was eluted with seven column volumes of $3 \mathrm{M} \mathrm{NaCl}$ in buffer A with absorbance monitored at OD 280. The fractions were pooled and concentrated by dialysis against $50 \%$ polyethylene glycol in buffer A.

This was then fractionated by gel filtration chromatography on Sephadex G-75 (Pharmacia) applied in a sample volume of 4-5\% of the column volume (column volume $=1.7 \mathrm{ml} / \mathrm{ml}$ of starting plasma). The column was eluted with buffer $A$ and the fraction of interest (the second peak) emerged at $\mathrm{Ve} / \mathrm{Vo}$ of 3.4. The fractions were pooled and dialyzed against buffer $\mathrm{A}$ to remove any $\mathrm{NaCl}$, then applied to a second Fast-Flow-S-Sepharose column $(20 \mathrm{ml}$ of column volume/liter of starting plasma). The bound protein peak was again eluted, collected, 
and concentrated as described above using buffer $\mathrm{A}$ without sodium azide. The ASP was dialyzed overnight and centrifuged to remove precipitate, and the protein concentration was measured by the method of Bradford using bovine serum albumin as a standard (13). Purification was monitored by SDS-15\% PAGE electrophoresis (14).

Tissue culture of human skin fibroblasts. Fibroblasts were obtained from forearm skin biopsies of all subjects. Primary cultures were established (15) and maintained in minimum essential medium with $10 \%$ fetal calf serum supplemented with penicillin-streptomycin $(100$ $\mathrm{IU} / \mathrm{ml}$ ). Fibroblasts were subcultured every $7-10 \mathrm{~d}$ with a split ratio of 1:1 or $1: 2$ after a 10 -min incubation with $0.25 \%$ trypsin in magnesium and calcium-free phosphate-buffered saline to detach cells from the flask. Cells were used for experiments between passages 5 and 15. For experiments, cells were plated out at a concentration of $1 \times 10^{5}$ cells per 60 - $\mathrm{mm}$ dish in $2 \mathrm{ml}$ of medium. On day 6 , cells were changed to a serum-free hormone medium of Dulbecco's minimum essential medium and Ham's F-12 (1:1) supplemented with insulin, biotin, calcium pantothenate, transferrin, triiodothyronine, and hydrocortisone (16).

Measurement of fibroblast triglyceride synthesis. On day 7, ASP and $\left[1-{ }^{14} \mathrm{C}\right]$ oleic acid $(\mathrm{sp}$ act $=52.6 \mathrm{Ci} / \mathrm{mol}$, Du Pont-New England Nuclear, Boston, MA) were added to the medium at the indicated concentrations (average sp act $=10 \mathrm{dpm} / \mathrm{pmol}$ ) and incubated for the specified times at $37^{\circ} \mathrm{C}$ in a $5 \% \mathrm{CO}_{2}$ humid incubator. The cells were then placed on ice and the medium removed, after which the cells were washed three times with $1 \mathrm{ml}$ of phosphate-buffered saline to removed excess free $\left[{ }^{14} \mathrm{C}\right]$ oleic acid. The cells were harvested by scraping with 2 $\times 1 \mathrm{ml}$ of phosphate-buffered saline using a rubber policeman and vortexed. Aliquots of the cell suspension were removed for protein determination as described above and for scintillation counting. The remaining suspension was extracted with a fivefold volume of chloroform/methanol/1 N HCl (20:10:0.025 vol/vol/vol) (17). After $30 \mathrm{~min}$, the sample was centrifuged $(2,000 \mathrm{rpm})$ for $10 \mathrm{~min}$ and the two phases were separated. The organic phase was evaporated under a flow of nitrogen and redissolved in chloroform/methanol (2:1), and applied to a silica gel plate for thin-layer chromatography in hexane/ether/acetic acid (85:15:1 vol/vol/vol) with reference lipids. The lipid spots were visualized by exposure to iodine vapor, and the spots were then scraped into vials with scintillation fluid and counted in a liquid scintillation counter.

Examination of ASP-fibroblast interactions. For these experiments, ASP was radioiodinated with iodine 125 by the chloramine-T method of Elder (18). The average specific activity obtained was 79 $\mathrm{cpm} / \mathrm{ng}$ protein and $95 \%$ of the radioactivity was precipitable by incubation with $10 \%$ trichloroacetic acid. To study specific binding of ASP, aliquots of fibroblasts were precooled on ice $\left(4^{\circ} \mathrm{C}\right)$ for $15 \mathrm{~min}$ and ${ }^{125} \mathrm{I}$-ASP added to the medium at the desired concentrations and incubated at $4^{\circ} \mathrm{C}$ for $2 \mathrm{~h}$. The medium was removed and the cells were then washed three times with $2 \mathrm{mg} / \mathrm{ml}$ bovine serum albumin in phosphate-buffered saline, and then three times with phosphate-buffered saline. The samples were collected by scraping, or by dissolution in 0.1 $\mathrm{N} \mathrm{NaOH}$ for $1 \mathrm{~h}$. An aliquot of the cell suspension was taken for counting in a gamma counter and for protein determination. Nonspecific binding was measured by adding a 20 -fold excess of unlabelled ASP to the media before the addition of labeled ASP (19). Specific binding was calculated as the difference between total and nonspecific binding. Results are expressed as nanograms of ASP bound per milligram of cell protein. Scatchard analyses were performed as described (20)

Internalization and degradation of ASP was also determined. To do so, cells were preincubated in serum-free hormone medium (as described above) for $24 \mathrm{~h}$, followed by incubation at $37^{\circ} \mathrm{C}$ for $4-24 \mathrm{~h}$ in the presence of $\left[1-{ }^{14} \mathrm{C}\right]$ oleic acid and ${ }^{125} \mathrm{I}$-ASP at the indicated concentrations. After the incubation the media was removed and the cells were washed and harvested by scraping as described above. Aliquots of cells were counted for ${ }^{125}$ I radioactivity and their protein content was determined. ${ }^{125} \mathrm{I}$ degradation products in the media were measured after precipitation with $60 \%$ trichloroacetic acid (final concentration $10 \%$ ) with the addition of $1 \mathrm{mg} / \mathrm{ml}$ bovine serum albumin (final con- centration) as carrier (21). The medium was centrifuged for $15 \mathrm{~min}$ at $2,000 \mathrm{rpm}$. Free iodine in the supernatant was then precipitated with $5 \% \mathrm{AgNO}_{3}$ (final $\mathrm{AgNO}_{3}$ concentration 1.7\%). An aliquot from the supernatant containing the degradation products was then counted in a gamma counter for ${ }^{125}$ I radioactivity.

Measurement of $L D L$ binding. LDL was isolated between densities 1.019 and 1.063 by standard ultracentrifugal techniques (22), and the protein was measured as described above. LDL was iodinated by the iodine monochloride method of MacFarlane as modified by Bilheimer et al. (23). The average specific activity obtained was $216 \mathrm{cpm} / \mathrm{ng}$, and $95 \%$ of the radioactivity was precipitable by incubation with $10 \%$ trichloroacetic acid. LDL binding was performed in the same manner as described for ASP binding in the absence (total binding) and the presence (nonspecific binding) of a 20 -fold excess of LDL. Specific binding was calculated as the difference between total and nonspecific binding.

Statistics. All results are expressed as average \pm standard error of the mean (SEM). Student's $t$ test for two means was used for comparison between the different cell groups. Linear regression was used for the relations between cell bioactivity and lipid values and the significance was calculated by Pearson's correlation coefficient.

\section{Results}

Patients studied. The plasma lipid, lipoprotein lipid, and LDL apoB levels in all the subjects studied are listed in Table $I$. Cultured skin fibroblasts were obtained from eight normals. Of these, six were male, and two female, with ages ranging between 27 and 66 yr. 12 patients with hyperapoB were studied: 2 were female and 10 male; their ages ranged between 33 and 62 yr. Six had levels of LDL cholesterol less than the 95 percentile whereas six exceeded it. Of the first six patients, one also had elevated fasting plasma triglyceride levels whereas, of the other six, plasma triglyceride was increased in three. Thus the lipoprotein phenotypes present within the hyperapoB group include five normal, three type II A, and three II B, and one type IV hyperlipoproteinemia. Three patients with heterozygous familial hypercholesterolemia were studied, and, in addition, four cell lines obtained from the American Tissue Culture Collection, Rockville, MD, cell bank were also examined. Of these, all were from patients said to be homozygous for familial hypercholesterolemia. The final group consisted of four patients with type IV hyperlipoproteinemia with a normal LDL apoB.

ASP stimulation of triglyceride synthesis. The results are shown in Fig. 1. In Fig. $1 A$ are the results obtained with the normal cells. It is evident that as ASP concentration was increased, cellular triglyceride synthesis, expressed as percent stimulation above baseline, increased until a plateau was reached. In the next three panels, the results in the other three groups are presented.

In all cases, baseline activity, that is, the rate of triglyceride synthesis in the absence of ASP, did not differ significantly. There were no significant differences in the response of triglyceride synthesis to ASP in the cells from patients with familial hypercholesterolemia (Fig. $1 C$ ) and those from the patients with type IV hyperlipoproteinemia without hyperapoB (Fig. 1 $D$ ) compared to the normals, the average increase being $58 \%$ and $53 \%$ respectively above baseline.

By contrast, the response of the hyperapoB cells to ASP was considerably blunted (Fig. $1 B$ ) in that it was significantly less at all concentrations of ASP, with an average maximal increase of $13 \%$. Moreover, it should be noted that there was no significant difference in the response of the hyperapoB cells 


\begin{tabular}{|c|c|c|c|c|c|c|c|c|c|}
\hline & $n$ & Age & Sex & $\begin{array}{l}\text { Plasma total } \\
\text { cholesterol }\end{array}$ & $\begin{array}{l}\text { Plasma total } \\
\text { triglyceride }\end{array}$ & HDL cholesterol & LDL cholesterol & Plasma LDL apoB & C/B \\
\hline & & & \multicolumn{7}{|c|}{$m g / d l$} \\
\hline \multicolumn{10}{|l|}{ Normal } \\
\hline 2,000 & & 27 & $\mathbf{F}$ & 156 & 80 & 82 & 58 & 56 & 1.04 \\
\hline 6,000 & & 66 & $\mathbf{M}$ & 156 & 80 & 40 & 100 & 100 & 1.00 \\
\hline 9,000 & & 44 & $\mathbf{M}$ & 180 & 122 & 38 & 118 & 99 & 1.19 \\
\hline 6,500 & & 27 & $\mathbf{M}$ & 170 & 43 & 55 & 106 & 54 & 1.97 \\
\hline 1,000 & & 42 & $\mathbf{M}$ & 146 & 100 & 38 & 88 & 70 & 1.26 \\
\hline 2,700 & & 39 & $F$ & 196 & 84 & 85 & 91 & 64 & 1.42 \\
\hline 7,000 & & 45 & $\mathbf{M}$ & 179 & 123 & 52 & 102 & 90 & 1.13 \\
\hline 0000 & & 39 & $\mathbf{M}$ & 156 & 82 & 51 & 89 & 65 & 1.36 \\
\hline \multicolumn{10}{|c|}{ HyperapoB } \\
\hline 3,000 & & 39 & $\mathbf{M}$ & 177 & 244 & 34 & 94 & 140 & 0.67 \\
\hline 5,000 & & 43 & $\mathbf{M}$ & 223 & 172 & 64 & 125 & 156 & 0.81 \\
\hline 4,500 & & 37 & $\mathbf{M}$ & 195 & 148 & 46 & 119 & 142 & 0.84 \\
\hline 9,500 & & 54 & $F$ & 261 & 122 & 64 & 173 & 156 & 1.11 \\
\hline 1,100 & & 54 & $\mathbf{M}$ & 236 & 199 & 36 & 160 & 123 & 1.30 \\
\hline 4,000 & & 40 & $\mathbf{M}$ & 249 & 329 & 51 & 132 & 155 & 0.85 \\
\hline 8,000 & & 41 & $\mathbf{M}$ & 350 & 132 & 35 & 289 & 213 & 1.35 \\
\hline 1,500 & & 33 & $\mathbf{M}$ & 296 & 170 & 55 & 207 & 160 & 1.29 \\
\hline 2,300 & & 67 & $\mathbf{M}$ & 288 & 302 & 38 & 190 & 150 & 1.27 \\
\hline 1,400 & & 59 & $\mathrm{~F}$ & 368 & 311 & 44 & 262 & 184 & 1.42 \\
\hline 2,400 & & 62 & $\mathbf{M}$ & 361 & 531 & 39 & 216 & 149 & 1.45 \\
\hline 2,600 & & 59 & $\mathbf{M}$ & 299 & 355 & 38 & 190 & 146 & 1.30 \\
\hline \multicolumn{10}{|c|}{ Familial hypercholesterolemia } \\
\hline $3,700^{*}$ & & 11 & $\mathbf{M}$ & & & & & & \\
\hline $3,600^{*}$ & & 13 & $\mathrm{~F}$ & & & & & & \\
\hline $3,400^{*}$ & & 16 & $\mathbf{M}$ & & & & & & \\
\hline $3,800^{*}$ & & 25 & $\mathbf{F}$ & & & & & & \\
\hline 4,100 & & 63 & $\mathbf{M}$ & 560 & 239 & 34 & 478 & 247 & 1.94 \\
\hline 6,100 & & 18 & $\mathbf{M}$ & 349 & 185 & 45 & 267 & 112 & 2.38 \\
\hline 1,200 & & 68 & $\mathbf{F}$ & 499 & 403 & 43 & 375 & 181 & 2.07 \\
\hline \multicolumn{10}{|c|}{ Type IV-normal B } \\
\hline 7,500 & & 52 & $\mathbf{M}$ & 309 & 1160 & 29 & 48 & 93 & 0.52 \\
\hline 3,900 & & 64 & $\mathbf{M}$ & 195 & 230 & 42 & 107 & 97 & 1.10 \\
\hline 4,200 & & 60 & $\mathbf{M}$ & 206 & 323 & 44 & 97 & 91 & 1.07 \\
\hline 4,300 & & 55 & $\mathbf{M}$ & 220 & 612 & 26 & 72 & 90 & 0.80 \\
\hline
\end{tabular}

Abbreviation: $\mathrm{C} / \mathrm{B}$, ratio of plasma LDL cholesterol to plasma LDL apoB. ${ }^{*}$ Cells from American Tissue Culture Collection from patients with homozygous familial hypercholesterolemia, plasma lipid values not available.

based on the lipoprotein phenotype in the patient. As shown in Fig. 2, both normocholesterolemic hyperapoB $(A)$ and hypercholesterolemic hyperapoB $(B)$ fibroblasts had markedly reduced responsiveness to ASP.

Studies of radioiodinated ASP cellular interaction. The interaction of radioiodinated ASP with the normal and hyperapoB cells was then studied. As shown in Fig. 3, cell-associated ${ }^{125} \mathrm{I}$-ASP increased relative to ASP medium concentration in the normal cells. As well, ASP was rapidly degraded by the normal cells as evidenced by the accumulation of ASP degradation products in the medium. There were also ASP concentration-dependent increases in cell-associated ASP observed in the hyperapoB cells as well as of ASP degradation products in the medium. However, in both instances, the amounts were substantially less than that observed in the normal cells at the highest concentration of ASP $(58 \%$ and $55 \% P<0.025$ and 0.01 respectively).

Binding of ASP to normal and hyperapoB cells was examined. Representative binding curves are shown for a normal and a hyperapoB cell line in Fig. 4. Total binding is measured with increasing concentration of ${ }^{125} \mathrm{I}$-ASP. Nonspecific binding is measured in the presence of a 20 -fold excess of unlabelled ASP. Specific binding is the difference between total and nonspecific binding. The data indicate that ASP exhibits the properties of specific and saturable binding to the normal cells. As analyzed by Scatchard linear regression (Fig. 5), the specific binding isotherms are linear, consistent with the presence of a single class of binding sites with a binding constant $\left(K_{d}\right)$ of 1.05 $\times 10^{-6} \mathrm{M}$. Specific binding of ASP to the hyperapoB cells, however, is substantially less than to the normal cells. The 

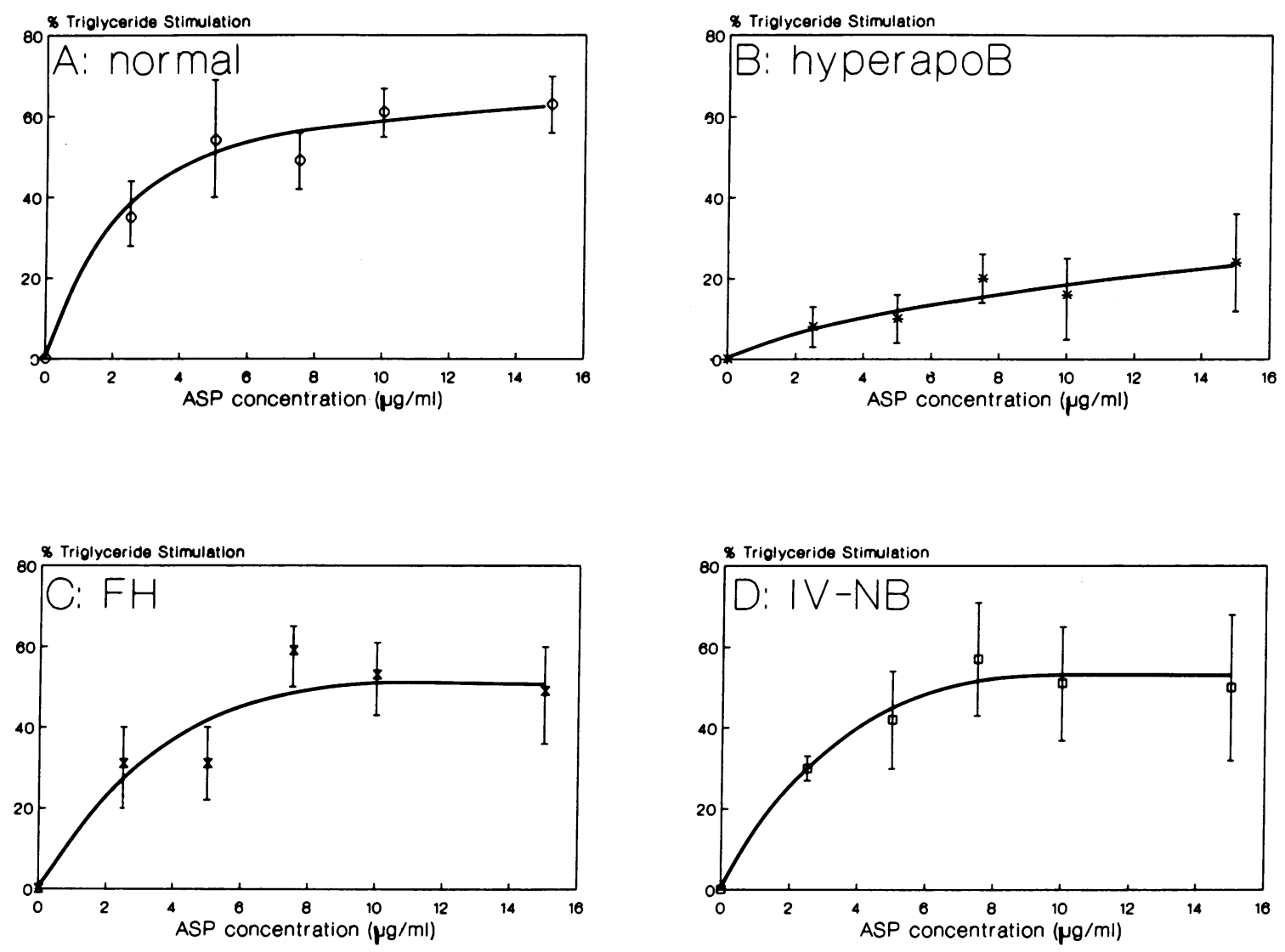

Figure 1. ASP stimulation of triglyceride synthesis in human skin fibroblasts. Cells were incubated with $10 \mu \mathrm{M}\left[{ }^{14} \mathrm{C}\right]$ oleate and increasing concentrations of ASP for $20 \mathrm{~h}$ and the amount of radioactive triglyceride was determined. Results are expressed as percentage increase over baseline (mean \pm SEM) triglyceride synthesis which is taken as $0 \%$. $(A)$ Eight normal cell lines $(0) ;(B) 12$ hyperapoB cell lines $(*) ;(C)$ seven FH cell lines $(\times) ;(D)$ four type IV normal LDL apoB cell lines $(\square)$.

slopes of the two lines are virtually identical $[-0.068 \pm 0.01$ $(\mu \mathrm{g} / \mathrm{ml})^{-1}$ normal vs. $-0.08 \pm 0.02$ hyperapoB, $P$ NS], whereas the $x$-intercept in the hyperapoB cells is almost exactly half that in the normal cells $(1.313 \pm 0.13 \mathrm{ng} / \mathrm{mg}$ cell protein normal vs. $0.76 \pm 0.10 \mathrm{ng} / \mathrm{mg}$ cell protein hyperapoB, $P<0.0025)$. These results point to a single class of receptors for ASP on the cell surface of both the normal and hyperapoB cells. However, the number of these receptors, on average, appear to be reduced by half in the hyperapoB cells.

The individual results of ASP specific binding in the normals and hyperapoB patients studied are shown in Fig. 6 . The average ASP binding in the normals was calculated based on the $x$-intercept from the Scatchard linear regression analysis $(1.313 \mathrm{ng} / \mathrm{mg}$ cell protein) which was taken as $100 \%$. Individual Scatchard results for each cell line were then compared to the average in normals. A range in ASP binding in both groups is evident. The ASP binding in the normals was $103 \% \pm 10.3$ and in the hyperapoB $64 \% \pm 7.1$. However, in none of the hyperapoB patients did binding of ASP exceed $100 \%$. In eight, it was $80 \%$ or less and in five it was $50 \%$ or less. Although, overall, the hyperapoB cell lines show reduced responsiveness to ASP, this specific defect appears to be more characteristic of some HyperapoB cell lines than others.

The results of ASP-specific binding for the familial hypercholesterolemia cells and the type IV-normal apoB cells are shown in Fig. 7, $A$ and $B$. Neither differs significantly from the normal. These findings, of course, are consistent with the earlier observations of a normal increase in triglyceride synthesis induced by ASP (Fig. 1). The relation between ASP binding and subsequent stimulation of triglyceride synthesis is shown in Fig. 8 for all of the cell lines studied. A significant direct relation, with however substantial scatter, between ASP binding and triglyceride synthetic response is evident.

The results for LDL binding are shown in Fig. 9. The normal cells are depicted in the top panel; the hyperapoB and the familial hypercholesterolemic group are shown in the succeeding panels. Except for those known to have familial hypercholesterolemia (bottom panel), the results are normal. As anticipated, LDL binding was markedly reduced in the cell lines from patients with heterozygous familial hypercholesterolemia and severely reduced in the cell lines from the patients with homozygous familial hypercholesterolemia.

Finally, the relation between the ASP-specific binding measured in vitro and the in vivo plasma lipid, lipoprotein lipid, and LDL apoB levels were examined using linear regression and Pearson's correlation coefficient. Because the metabolic defect which produces the elevated LDL particle number in plasma in familial hypercholesterolemia has been delineated, this group was excluded. For all the rest there was no significant relation between ASP-specific binding to human fibroblasts and the corresponding plasma triglyceride or HDL cholesterol levels. However, there were significant inverse re- 

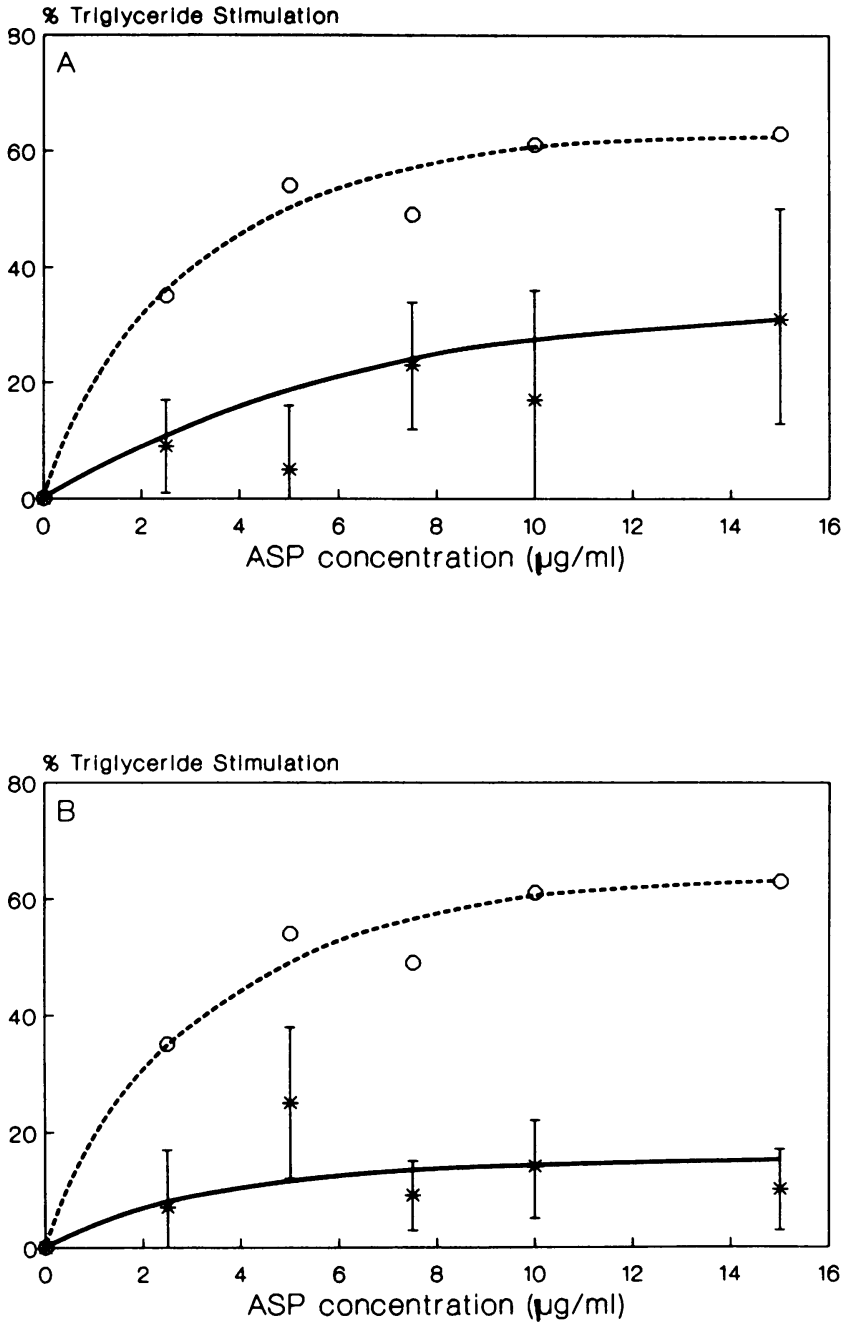

Figure 2. ASP stimulation of triglyceride synthesis in normocholesterolemic and hypercholesterolemic hyperapoB. Cells were incubated as described in Fig. 1. (A) Six normocholesterolemic hyperapoB (*) and $(B)$ six hypercholesterolemic hyperapoB $(*)$. In both panels, eight normals (O) are shown in the dotted lines. Results are expressed as percentage stimulation over baseline $(0 \%) \pm$ SEM. lations between ASP specific binding and total and LDL cholesterol with correlation coefficients of 0.56 and 0.71 and $P$ values of $<0.005$ and 0.0005 respectively. The highest correlation coefficient, $0.76 P<0.0001$, was to LDL apoB, which also demonstrated the most negative slope $(-0.632$, Fig. 10). It is of interest that, if the analysis is confined to the normolipidemic patients with hyperapoB and the normals, then the only plasma variable that correlates with ASP-specific binding is the level of LDL apoB. Though not shown, the same findings result if the ASP-induced increase in cell triglyceride synthesis is correlated against plasma levels of the total lipids, lipoprotein lipids, and LDL apoB.

\section{Discussion}

Hyperapobetalipoproteinemia is defined as the lipoprotein phenotype characterized by an increased LDL particle number in plasma owing to overproduction of hepatic apoB lipoproteins (2). However, no specific cause for the hepatic overproduction of apoB particles has yet been recognized; nor has any cell-specific marker of the disorder been suggested. The present study has examined the capacity of ASP to bind to, and stimulate triglyceride synthesis in human cultured skin fibroblasts. The results in the patients with hyperapoB stand apart from those obtained in normals, in patients with familial hypercholesterolemia, and in patients with type IV hyperlipoproteinemia with normal LDL apoB.

The data confirm that ASP markedly stimulates triglyceride synthesis in skin fibroblasts cultured from normals. However, the same degree of stimulation was observed in fibroblasts obtained from patients with familial hypercholesterolemia and patients with type IV hyperlipoproteinemia without hyperapoB. Furthermore, the binding of ASP was specific and saturable with a $K_{d}$ of $1.05 \times 10^{-6} \mathrm{M}$ in the normal cells. Similarly, in familial hypercholesterolemia and type IV hyperlipoproteinemia without hyperapoB, specific saturable binding of ASP to a single class of receptors was demonstrated and the maximal binding obtained was essentially the same as in the normal group. By contrast, the increase in triglyceride synthesis induced by ASP in skin fibroblasts cultured from patients

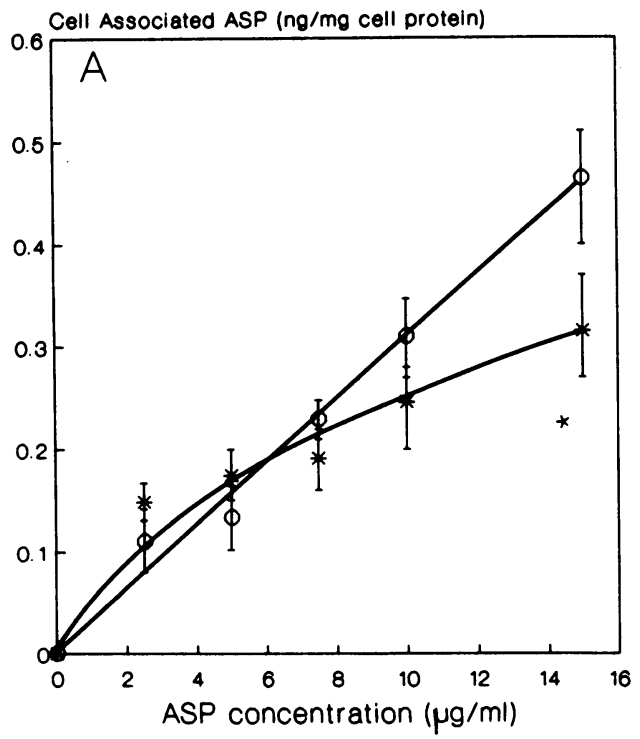

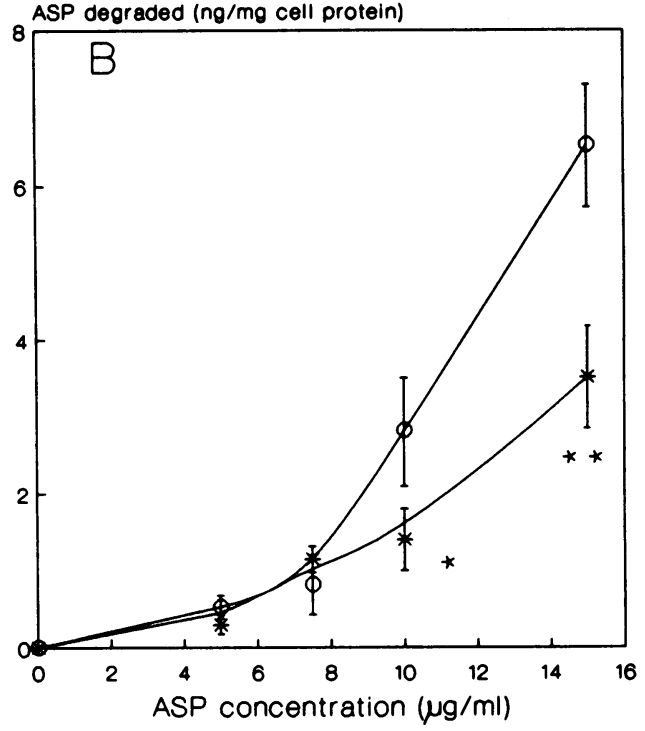

Figure 3. Cell associated and cell degraded ASP in normal and hyperapoB cells. Cells were incubated with $10 \mu \mathrm{M}$ $\left[{ }^{14} \mathrm{C}\right]$ oleate and increasing concentrations of ${ }^{125} \mathrm{I}$-ASP for $20 \mathrm{~h}$, and the amount of ASP associated with the cell and the degradation products in the media were measured. Results are the average of 8 normal $(0)$ and 12 hyperapoB (*) cell lines expressed as nanograms of ASP per milligram of cell protein \pm SEM. $P$ values: ${ }^{*} P$ $<0.025,{ }^{* *} P<0.01$. 

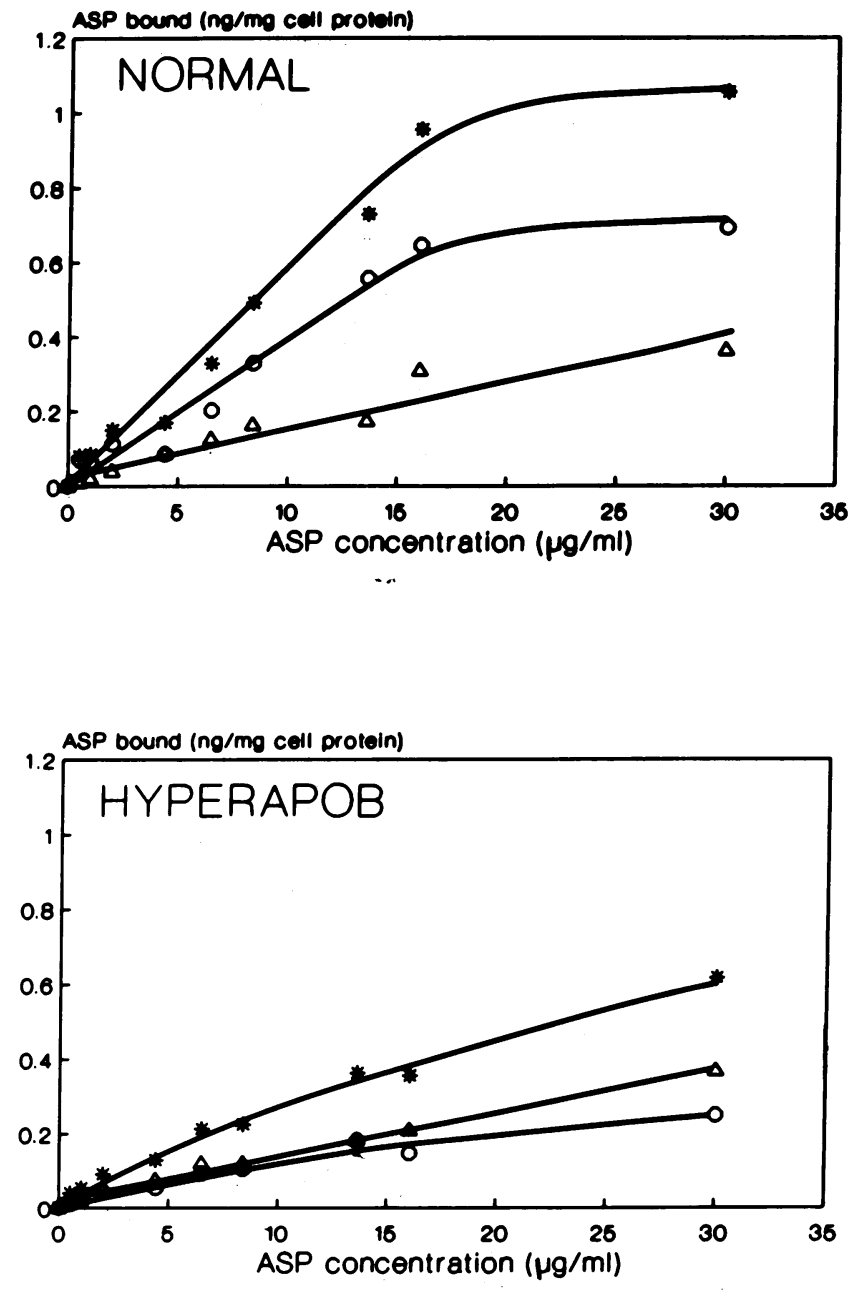

Figure 4. ASP binding to a representative normal and hyperapoB cell. ${ }^{125} \mathrm{I}$-ASP total, nonspecific, and specific binding was measured at $4^{\circ} \mathrm{C}$ for $2 \mathrm{~h}$ as described in methods. (*) Total binding; $(\Delta)$ nonspecific binding; (O) specific binding. Results are expressed as nanograms of ASP per milligram of cell protein.

with hyperapoB was markedly less. At the same time, although specific saturable binding to ASP was evident, the maximal specific binding of ASP to these cells was considerably reduced because, it seems, of a reduced number of specific receptors in the cell membrane.

This line of research began with the hypothesis that the rate of uptake of fatty acids into key peripheral tissues such as adipocytes might be reduced in patients with hyperapoB. As a consequence of this, the flux of fatty acids to the liver might increase, resulting in turn in increased hepatic apoB synthesis and secretion. In support of this hypothesis were the observations that chylomicron triglyceride clearance was reduced in patients with hyperapoB (24) and the in vitro observations that the rate of triglyceride synthesis in adipose tissue obtained from patients with hyperapoB was less than in similar tissue obtained from normals (25). It was these findings that suggested the experiments examining triglyceride synthesis in normal and hyperapoB fibroblasts which led to the recognition of ASP (5).

The mechanism of action of ASP remains to be elucidated.

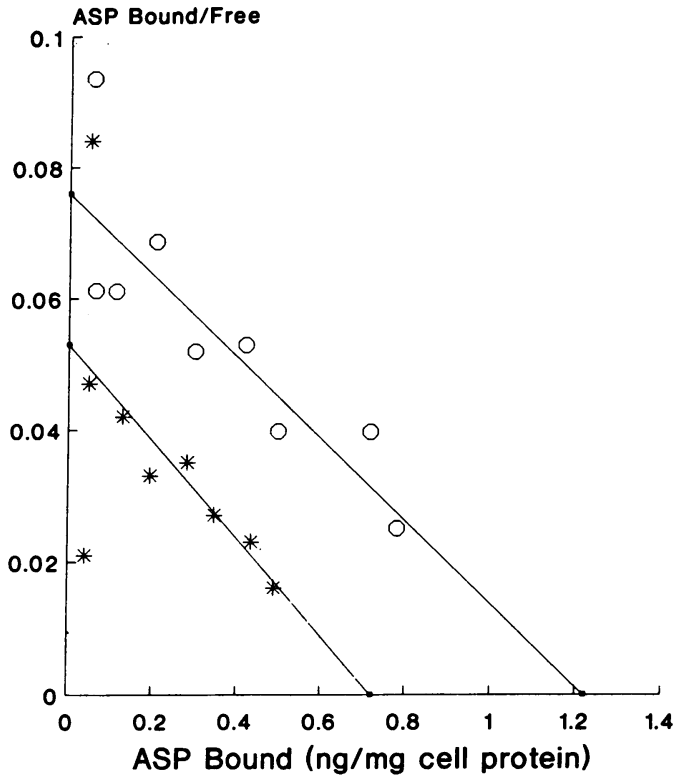

Figure 5. Scatchard analysis of ASP specific binding. Scatchard analysis of bound ASP vs. bound/free ASP. Normal (0): $n=7$, slope $=-0.068 \pm 0.01(\mu \mathrm{g} / \mathrm{ml})^{-1}, x$-intercept $=1.313 \pm 0.13 \mathrm{ng} / \mathrm{mg}$ cell protein, $r=0.610$; hyperapoB $(*): n=10$, slope $=-0.080 \pm 0.02(\mu \mathrm{g} /$ $\mathrm{ml})^{-1}, x$-intercept $=0.76 \pm 0.10 \mathrm{ng} / \mathrm{mg}$ cell protein, $r=0.863$.

The present study establishes that the ASP-induced increase in cellular triglyceride synthesis is related to the degree of ASP binding to the cell. Similarly, although the in vitro effectiveness of ASP appears clear, much remains to be done to establish whether or not it plays an important metabolic role in vivo. In this regard, it should be noted that ASP levels in

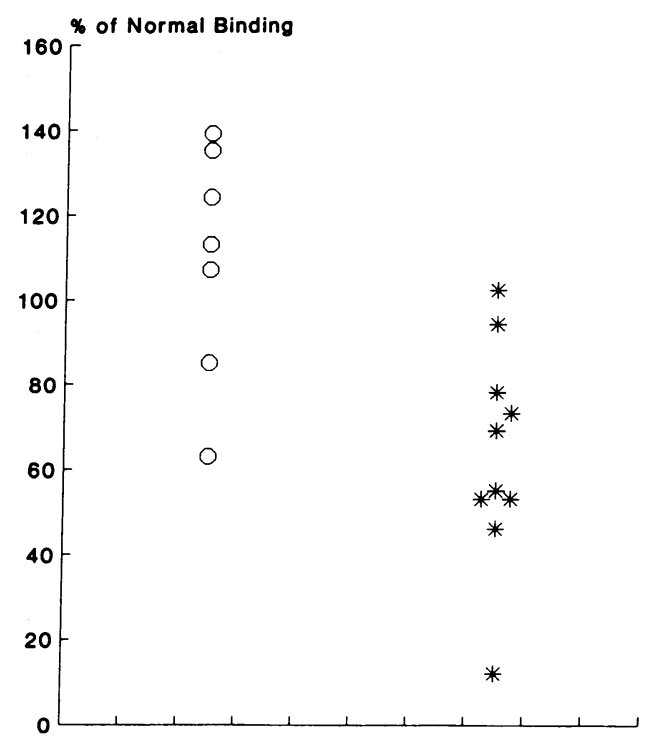

Figure 6. Distribution of ASP binding in normal and hyperapoB. Percentage of normal binding was calculated for each cell line as Scatchard $x$-intercept for each cell line divided by the average Scatchard $x$-intercept $(1.313 \mathrm{ng} / \mathrm{mg}$ cell protein) $\times 100$ for 7 normals $(0)$ and 10 hyperapoB $(*)$. 

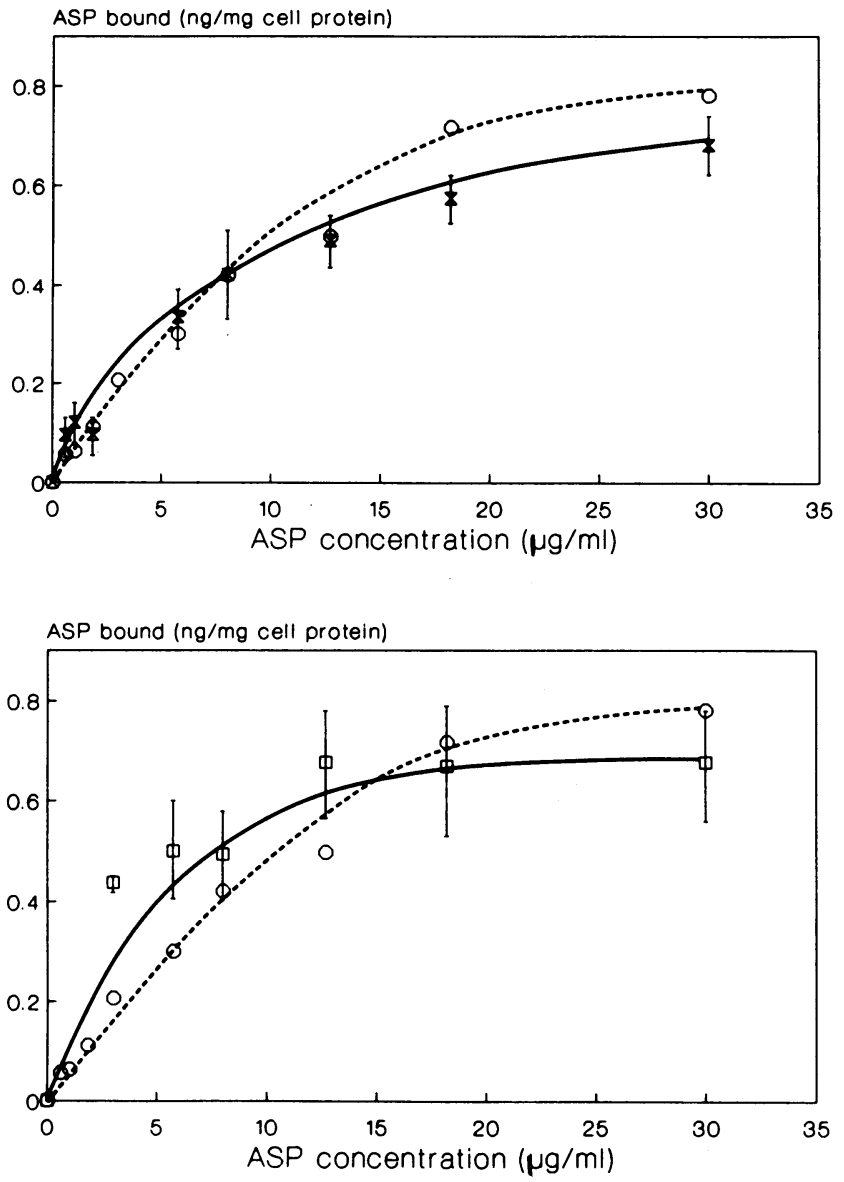

Figure 7. ASP-specific binding in familial hypercholesterolemia and type IV-normal LDL apoB cells. ASP-specific binding was measured at $4^{\circ} \mathrm{C}$ for $2 \mathrm{~h}$ as described in methods. (Upper panel) Seven familial hypercholesterolemia $(x)$ cell lines; and (lower panel) four type IVnormal LDL apoB (ㅁ) cell lines with the normal ASP binding (O) shown in both panels as the dotted line. Results are given as average ASP bound in nanograms per milligram cell protein \pm SEM.

\$ Triglyceride Stimulation

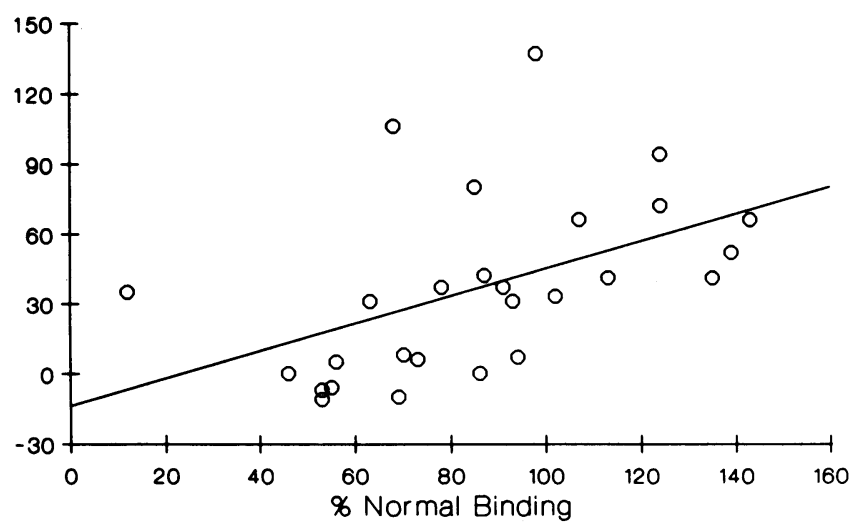

Figure 8. Relation between ASP binding and ASP stimulation of triglyceride synthesis. Percent normal binding for all of the cell lines (normal, hyperapoB, familial hypercholesteremia, and type IV-normal B) is plotted individually against the maximal percent triglyceride stimulation by ASP for the same cell line. Linear regression analysis: $r=0.486, P<0.005$.
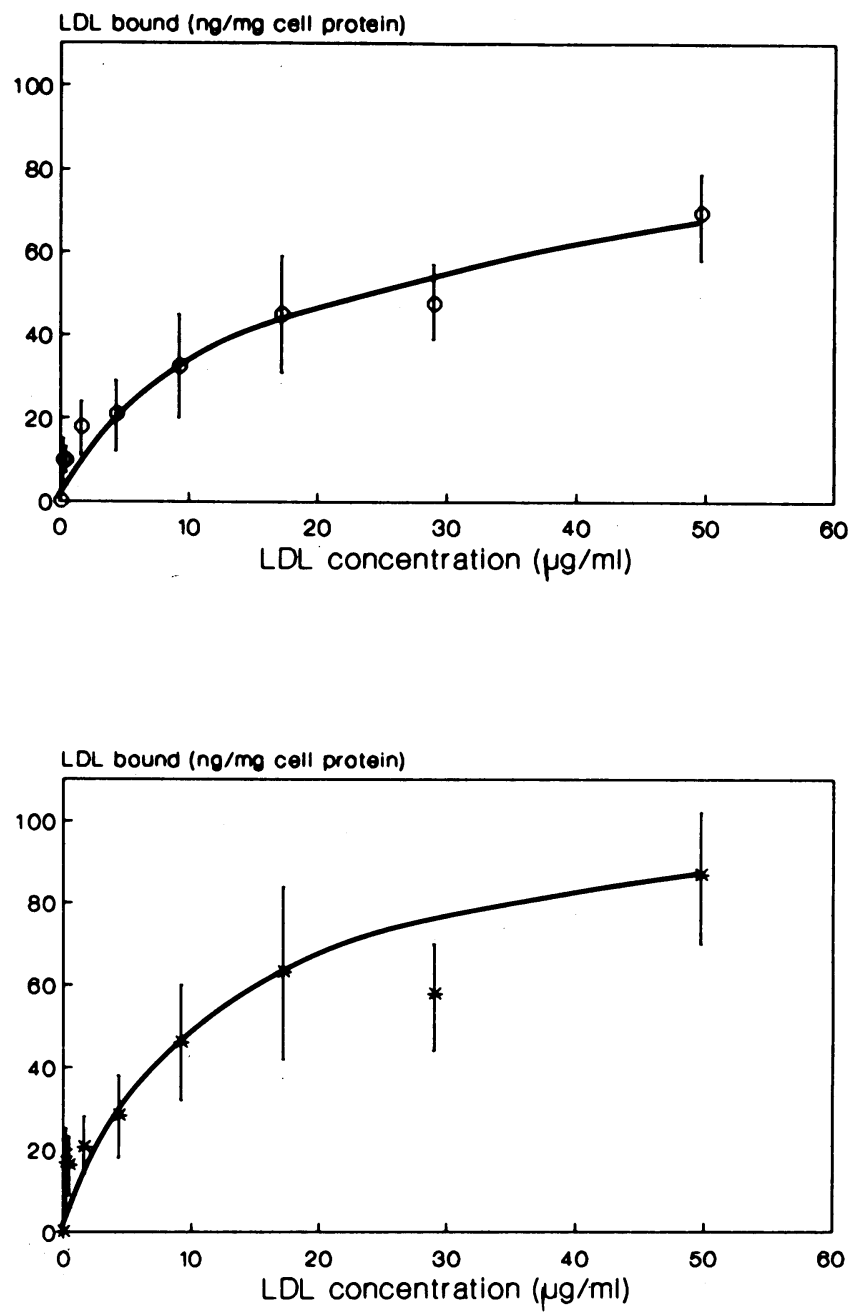

LDL bound (ng/mg cell protein)

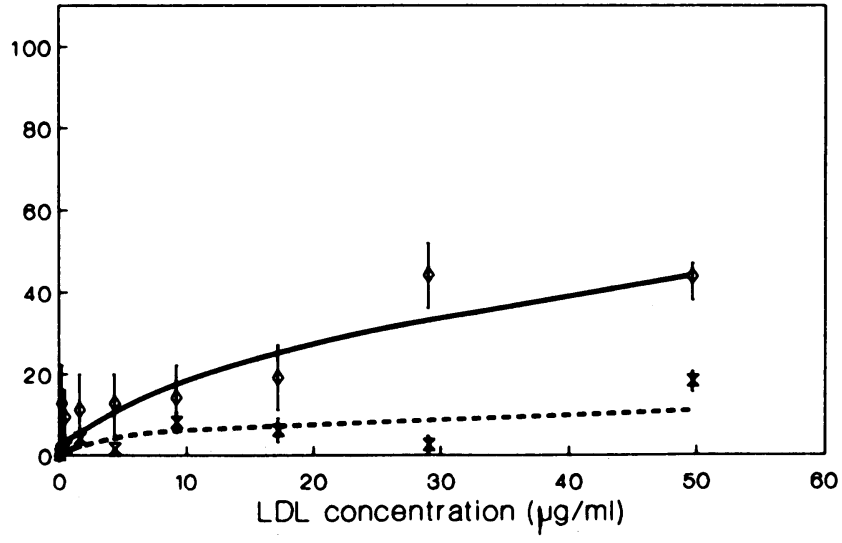

Figure 9. LDL-specific binding in normal, hyperapoB and familial hypercholesterolemia (FH) cells. LDL-specific binding was measured at $4^{\circ} \mathrm{C}$ for $2 \mathrm{~h}$ as described in Methods. (Upper panel) 6 normal (O) cell lines; (middle panel) 10 hyperapoB (*) cell lines; and (lower panel) 3 heterozygous FH cell lines (solid line) and 4 homozygous FH cell lines (dotted line). Results are expressed as nanograms LDL bound per milligram cell protein \pm SEM. 


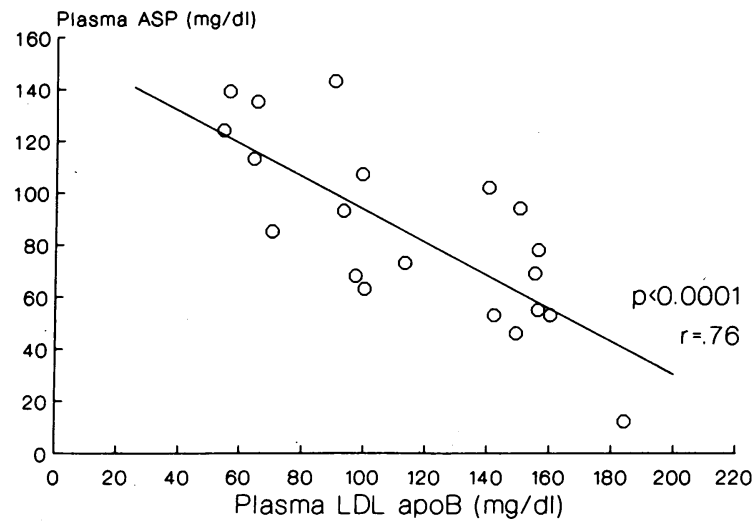

Figure 10. ASP binding relation to plasma LDL apoB. Plasma LDL apoB is plotted against ASP binding expressed as a percentage of the average normal ASP binding. Each of the normal, hyperapoB, and type IV-normal B cell lines are plotted individually. Linear regression analysis: $r=0.76$ with $P<0.0001$.

plasma increase after an oral fat load, paralleling the changes in plasma triglyceride levels, but do not change after an oral glucose load (26). The plasma response of ASP, therefore, appears to be appropriate to the stimulus.

If ASP is important in the regulation of the rate of fatty acid uptake in tissues where triglyceride synthesis is active, then it follows that a reduced number of ASP receptors in such tissues might result in reduced fatty acid uptake, and therefore might result in diversion of fatty acids to the liver. This would then result in overproduction of VLDL and LDL. The physiologic validity of this hypothesis is not tested in this study; but the relations observed between ASP binding and ASP stimulation of triglyceride synthesis and the level of plasma LDL apoB did coincide with those predicted. That is to say, with the exception of the patients with familial hypercholesterolemia where LDL apoB levels are elevated because of a fault in catabolism, there was a significant inverse relation between both parameters of ASP-cell interaction and the concentration of LDL in plasma. Such a relation was not seen for either VLDL or HDL.

Finally, it must be emphasized that hyperapoB is a phenotype not a genotype, and given its frequency, more than one cause is almost certain to exist. In this study, not all of the hyperapoB patients had reduced ASP receptors on their fibroblasts; further given the considerable homology that has been demonstrated between familial combined hyperlipidemia and hyperapoB, the finding by Babirak et al. (27) that some of their patients also had reduced lipoprotein lipase levels is consistent with the view that hyperapoB has multiple etiologies. In the present instance, it remains to be shown that reduced ASP receptor number will be a faithful cell marker of the disorder within families with hyperapoB. While these limitations must not be ignored, the opportunity the present findings afford to explore the pathogenesis and genetics of hyperapoB must not be lost sight of as well.

\section{Acknowledgments}

This research was supported by The Medical Research Council of Canada (MA-5480).

\section{References}

1. Langer, T., W. Strober, and R. I. Levy. 1972. The metabolism of low density lipoprotein in familial type II hyperlipoproteinemia. $J$. Clin. Invest. 51:1528.

2. Teng, B., A. D. Sniderman, A. K. Soutar, and G. R. Thompson. 1986. Metabolic basis of hyperapobetalipoproteinemia: turnover of apolipoprotein B in low-density lipoproteinemia and its precursors and subfractions compared with normal and familial hypercholesterolemia. J. Clin. Invest. 77:663-672.

3. Cianflone, K., P. O. Kwiterovich, Jr., M. Walsh, A. Forse, M. A. Rodriguez, and A. D. Sniderman. 1987. Stimulation of fatty acid uptake and triglyceride synthesis in human cultured skin fibroblasts and adipocytes by a serum protein. Biochem. Biophys. Res. Commun. 144:94-100.

4. Cianflone, K., M. A. Rodriguez, M. Walsh, H. Vu, and A. D. Sniderman. 1988. The effect of a plasma protein fraction on lipid synthesis in cultured skin fibroblasts from normals and patients with hyperapobetalipoproteinemia. Clin. Invest. Med. 11:99-107.

5. Cianflone, K., A. D. Sniderman, M. J. Walsh, H. Vu, J. Gagnon, and M. A. Rodriguez. 1989. Purification and characterization of acylation-stimulating protein. J. Biol. Chem. 264:426-430.

6. Lipid Research Clinics Program. 1974. Manual of Laboratory Operations. Volume 1. Lipids and Lipoprotein Analysis. DHEW Publication No. (NIH) 75-628.

7. Friedewald, W., R. Levy, and D. Fredrickson. 1972. Estimation of the concentration of low-density lipoprotein cholesterol in plasma, without use of the preparative ultracentrifuge. Clin. Chem. 18:499502.

8. Sniderman, A. D., B. Teng, and M. Jerry. 1975. Determination of B protein of low density lipoprotein directly in plasma. J. Lipid Res. 16:465-467.

9. The Lipid Research Clinics Program Prevalence Study. 1979. Circulation. 60:427-452.

10. Sniderman, A. D., S. Shapiro, D. G. F. Marpole, B. F. Skinner, B. Teng, and P. O. Kwiterovich, Jr. 1980. Association of coronary atherosclerosis with hyperapobetalipoproteinemia [increased protein but normal cholesterol levels in human plasma low-density (B) lipoproteins]. Proc. Natl. Acad. Sci. USA. 77:604-608.

11. Teng, B., G. Thompson, A. D. Sniderman, T. M. Forte, R. M. Kraus, and P. O. Kwiterovich, Jr. 1983. Composition and distribution of low-density lipoprotein fractions in hyperapobetalipoproteinemia, normolipidemia and familial hypercholesterolemia. Proc. Natl. Acad. Sci. USA. 80:6662-6666.

12. Brown, M. S., and Goldstein, J. L. 1975. Familial hypercholesterolemia. Genetic, biochemical and pathophysiologic considerations. Adv. Intern. Med. 20:273-296.

13. Bradford, M. 1976. A rapid and sensitive method for the quantitation of microgram quantities of protein utilizing the principal of protein-dye binding. Anal. Biochem. 72:248-254.

14. Laemmli, U. 1970. Cleavage of structural proteins during the assembly of the head of bacteriophage T4. Nature (Lond.). 227:680685.

15. Freshney, I. 1983. Culture of Animal Cells: A Manual of Basic Technique. Alan R. Liss, Inc., New York.

16. Amorosa, L., A. Khachadurian, J. Harris, S. Schneider, and C. Fung. 1984. The effects of triiodothyronine, hydrocortisone and insulin on lipid synthesis by cultured fibroblasts preincubated in a serum free medium. Biochim. Biophys. Acta. 792:192-197.

17. Folch, J., M. Lee, and F. Sloan-Stanley. 1957. A simple method for the isolation and purification of total lipids from animal tissues. $J$. Biol. Chem. 226:497-509.

18. Elder, J. 1977. Radioiodination of proteins in single polyacrylamide gel slices. J. Biol. Chem. 252:6510-6515.

19. Innerarity, T., R. Pitas, and R. Mahley. 1986. Lipoprotein receptor interaction. Methods Enzymol. 129:542-565. 
20. Scatchard, G. 1949. The attraction of proteins for small molecules and ions. Ann. N. Y. Acad. Sci. 55:660-672.

21. Goldstein, J., S. Baar, and M. Brown. 1983. Receptor mediated endocytosis of low density lipoproteinemia in cultured cells. Methods Enzymol. 98:241-261.

22. Havel, R., H. Eder, and J. Bragson. 1955. The distribution and chemical composition of ultracentrifugally separated lipoproteins in human serum. J. Clin. Invest. 34:1345-1353.

23. Bilheimer, D. W., S. Eisenberg, and R. I. Levy. 1972. The metabolism of very low density lipoprotein proteins. I. Preliminary in vitro and in vivo observations. Biochim. Biophys. Acta. 260:212-221.

24. Genest, J., A. D. Sniderman, K. Cianflone, B. Teng, S. Wach- older, Y. L. Marcel, and P. O. Kwiterovich, Jr. 1986. Hyperapobetalipoproteinemia: plasma lipoprotein responses to oral fat load. Arteriosclerosis. 6:297-304.

25. Teng, B., A. Forse, M. A. Rodriguez, and A. D. Sniderman. 1988. Adipose tissue glyceride synthesis in patients with hyperapobetalipoproteinemia. Can. J. Pharmacol. Physiol. 66:239-242.

26. Cianflone, K., H. Vu, M. Walsh, A. Baldo, and A. D. Sniderman. 1989. The metabolic response of acylation stimulating protein to an oral fat load. J. Lipid Res. 30:1727-1733.

27. Babirak, S. P., P. H. Iverius, W. Y. Fujimoto, and J. D. Brunzell. 1989. Detection and characterization of the heterozygote state for lipoprotein lipase deficiency. Arteriosclerosis. 9:326-334. 